\title{
RESOURCE USE AND CROP PRODUCTIVITY IN A COLOPHOSPERMUM MOPANE TREE BASED AGRO- ECOSYSTEM IN INDIAN DESERT
}

\author{
SINGH, G.* - RATHOD, T.R. \\ Division of Forest Ecology, Arid Forest Research Institute, New Pali Road, Jodhpur-342005, \\ India \\ *Corresponding author \\ e-mail: singh_g_dr@yahoo.co.in; gsingh@icfre.org \\ (Received $16^{\text {th }}$ June 2009; accepted $5^{\text {th }}$ January 2012)
}

\begin{abstract}
A 9-year-old plantation of Colophospermum mopane (Kirk et Benth) kirk ex J. Leonard at a spacing of $5 \mathrm{~m} \times 5 \mathrm{~m}$ was selected to study tree crop interaction with a view to find out suitability of this species for integration in agriculture land. Different treatments were (i) fixed crop of Vigna radiata (FC), (ii) rotation crop (Vigna radiata rotated by non-legume crop, $\mathrm{RC}$ ) (iii) sole agriculture crop (AC), and (iv) sole tree (TC). Vigna radiata (L.) Wilczek (mungbean) was sown on 21 June 2003. Micro-plots of $1 \mathrm{~m} \mathrm{X}$ $1 \mathrm{~m}$ size were laid at $1 \mathrm{~m}$ (near), $2.5 \mathrm{~m}$ (middle of two trees) and $3.5 \mathrm{~m}$ (centre of four trees) from the selected trees for sampling and yield recording. Tree height, dbh and crown diameter differed significantly $(P<0.05)$ between the plots. Soil water content was lowest $(P<0.05)$ in tree-integrated plots but it increased in deeper soil layers. SWC varied through non-significant in August, lowest $(P<$ $0.05)$ at $1 \mathrm{~m}$ in September to significantly $(P<0.01)$ different between sampling distances in December 2003 suggesting exhaustive use of soil water by trees. Soil organic matter, available $\mathrm{PO}_{4}-\mathrm{P}, \mathrm{NO}_{3}-\mathrm{N}$ and $\mathrm{NH}_{4}-\mathrm{N}$ did not differ among the treatments and micro-plots though these nutrients differed in soil layers. Tree water use from 0-25 cm in August, $25-50 \mathrm{~cm}$ in September and 50-75 cm soil layer in December 2003 indicated a competitive nature of $C$. mopane with the associated $V$. radiata crop reducing population and yield up to a level of $97 \%$. Reduction in grain was relatively greater than husk (pods after grain removal). Seedling population and yield were lowest at $1 \mathrm{~m}$ distance and increased with distance from the trees. Leaf water status of $V$. radiata was highest at $1 \mathrm{~m}$ and it decrease with distance with a lowest value in AC plots. Relative neighbour effect values indicated a transition from strong competitive to weak facilitative nature of $C$. mopane and suggested the dominance of competitive effects during crop growth. Conclusively, integration of $C$. mopane reduces crop yield when rainfall is sufficient only for agriculture crop. Trenching around tree to reduce root overlapping between tree and agriculture crop and therefore competition for resources may be beneficial and enhance crop yield.
\end{abstract}

Keywords: Colophospermum mopane, competition for resources, crop yield, soil nutrients, soil water, $V$. radiata

\section{Introduction}

Trees growing in the agriculture land and community lands of Indian Desert minimize the risk of crop failure during drought and famines by providing fodder and fuel wood (Shankarnarayn et al., 1987; Singh et al., 2004). However, population of these are very less that requires further integration of trees to improve vegetation status and would be beneficial for the poor by providing top feed for livestock and fuel for energy generation. Trees have been found to facilitate regeneration of native and existing vegetation in forest plantation (Bone et al., 1997), sub-alpine and alpine plant communities (Callaway et al., 2002), desert communities (Vetaas, 1992) and the Middle East (Tielborger and Kadmon, 1995). However, there are also reports of neighbour interference through allelopathic suppression (Friedman et al., 1977) and competition for resources (Singh et al., 2001; Tielborger and Kadmon, 1997). In agriculture land, tree 
influences crop productivity (Aggarwal and Kumar, 1990; Brenan and Kessler, 1995) through soil improvement (Kater et al., 1992; Singh et al., 2000), microclimatic modification (Belsky et al., 1993) and soil water conservation (Gupta and Saxena, 1978). But limited resource availability in arid and semi-arid regions, the benefits of tree integration largely depends upon efficient and judicious management of soil and water resources. Therefore, selection of suitable tree species, an appropriate combination of tree and crop and development of suitable management practices like pruning, lopping, thinning and root clipping are important aspects to enhance productivity of an agroforestry system.

Many exotics like Eucalyptus, Prosopis, Acacia and Colophospermum etc. have been tried for their suitability to rehabilitate and to increase productivity of degraded lands because of their relatively higher growth as compared to the indigenous species (Hocking, 1993). However, before recommending into agriculture land it is necessary to study tree behaviours towards agriculture crop by studying tree crop interaction using systematically designed experiment. Colophospermum mopane (kirk et Benth) Kirk ex J. Leonard is an introduction to India from low altitude, high temperature regions of southern Africa and belongs to family Leguminoceae subfamily Caesalpinoideae (Bennet, 1983). It is a widespread tree of the drier parts of the Zambezian region and the river valleys of central and southern Africa (Coates, 1983). It is a preferred fuel wood and fodder species at its natural site. Because of its multipurpose uses this species has been planted to increase the productivity of degraded lands in Indian Desert. However, it is necessary to study the tree crop interaction in terms of competitive or facilitative effects on agriculture crops for its better uses in agroforestry or silvopastoral systems.

Therefore, present study was carried out to determine tree crop interactions in terms of resource use like photo-synthetically active radiations (PAR), soil water and soil nutrients and crop productivity and suggest suitable management strategy for better use of this species in enhancing productivity of dry lands.

\section{Materials and methods}

\section{Site conditions}

Study was conducted at the experimental farm of Arid Forest Research Institute, Jodhpur (Latitute $26^{\circ} 45^{\circ} \mathrm{N}$, Longitude $72^{\circ} 03 \mathrm{E}$ ) in Rajasthan, India. The climate of the site is tropical and characterized by hot and dry summer, hot rainy season, warm autumn and cool winter (dipping down to $2{ }^{0} \mathrm{C}$ ). Summer is the most dominant characterized by high temperature (reaching up to $49{ }^{0} \mathrm{C}$ in month of May) from March to mid July and experienced strong winds (usually $20-30 \mathrm{~km} \mathrm{~h}^{-1}$ ). The period from mid July to September is the monsoon season, which receives most of the rainfall, which varied widely between the years [27]. Soil of the experimental site is aridisol "coarse loamy, mixed, hyperthermic of Typic Camborthids" as per the USDA system of classification. Soil texture is loamy sand with soil $\mathrm{pH}$ of $8.48, \mathrm{EC}$ of $0.36 \mathrm{dSm}^{-1}$ and soil organic carbon of 0.203 in $0-75 \mathrm{~cm}$ soil layer. The depth of the soil is about $80 \mathrm{~cm}$, below which there is a hardpan of calcium carbonate aggregates called 'Kankar' of various sizes. Soil moisture storage in the upper $75 \mathrm{~cm}$ layer varies from $120 \mathrm{~mm}$ at $0.01 \mathrm{MPa}$ to $35 \mathrm{~mm}$ at $-1.5 \mathrm{MPa}$. 


\section{Experimental setup}

A 9-year-old plantation of Colophospermum mopane was selected for the experiment. Different treatment plots were (i) fixed crop plot of Vigna radiata only (FC), (ii) rotation crop plot i.e., Vigna radiata rotated by non-legume crops like Pennisetum glaucum (RC) in second year, (iii) sole agriculture crop plot (AC), and (iv) tree only plot (TC) in three replications. Each plot was of $20 \mathrm{~m} \times 15 \mathrm{~m}$ size with 12 experimental plants at the spacing of $5 \times 5 \mathrm{~m}$. Pennisetum glaucum was harvested in $\mathrm{RC}$ plot in 2001 whereas no crop sowing in 2002 because of severe drought. Therefore, Vigna radiata was sown in both the FC and RC plots on 21 June 2003 after $64.5 \mathrm{~mm}$ rain between 18 to 20 June 2003. In each plot, one tree was randomly selected and micro-plots of $1 \mathrm{~m}^{2}$ area were laid out at $1.0 \mathrm{~m}$ (near), $2.5 \mathrm{~m}$ (middle of two row of trees) and 3.5m (centre of four trees) from tree for sampling and observations recording on crop yield, soil water and soil nutrients. There were 12 plots (4 treatments X 3 replicates) in randomized block design.

\section{Observation recording}

Height, collar diameter, diameter at breast height (dbh) and crown diameter of $C$. mopane trees were recorded in June and December 2003. Percent increment in growth variables were calculated as: \% increment $=(x$ in December $-x$ in June $) \times 100 / x$ in June. Where $x$ is height, collar diameter, dbh or crown diameter. Photosynthetically active radiations (PAR) was measured at $1 \mathrm{~m}$ distance from tree trunk (under the canopy) as well as in the AC plots in September 2003 with portable $\mathrm{CO}_{2}$ gas analyser, model CI-301 (CT-301 PSO; CID, Vancouver, USA). Population of Vigna radiata seedlings was counted on 22 August 2003 from the micro-plots. Leaf samples of $V$. radiata were collected on $8^{\text {th }}$ and $16^{\text {th }}$ September 2003 at $14.00 \mathrm{hr}$ and fresh weight was recorded immediately. Leaf dry weight was recorded after drying the samples at $65{ }^{\circ} \mathrm{C}$ and leaf water content was calculated. Crop was harvested from the micro-plots on 31 October 2003 and grain, husk (pods after removal of grain) and holm (straw) yields (air-dried) were recorded after winnowing. A relative neighbour effect (RNE) was calculated following the method of Markham and Chanway (Markham and Chanway, 1996). RNE $=\left(X_{\mathrm{t}}-X_{\mathrm{c}}\right) / \mathrm{x}$ where $X$ was the performance variables of target species in absence $(\mathrm{t})$ and presence (c) of adult neighbours (i.e., C. mopane trees) and x was the higher of $X_{\mathrm{t}}$ or $X_{\mathrm{c}}$. Negative values of RNE indicated facilitation and positive values competition.

To find out the influence of $C$. mopane trees on soil nutrients and soil water, soil samples were collected from the micro-plots. Soil samples were collected in September (0-25 cm soil layer) and again in December 2003 (in 0-25, 25-50 and 50-75 cm soil layers) for soil nutrient analysis. For soil water, sampling was carried out in August (crop growing period), September (crop maturity) and December 2003 (after crop harvest). A single soil core was taken using a mechanical soil sampler and divided into 0-25, 25-50 and 50-75 cm layers to observe the soil water depletion in different soil layers. Soil water was determined gravimetrically after drying the soil at $105{ }^{\circ} \mathrm{C}$. Gravimetric soil water content was converted to $\mathrm{mm}$ using the following equation to give total soil water to the soil depth of $0-75 \mathrm{~cm}$. Soil water $($ in $\mathrm{mm})=\%$ soil water $\times$ soil depth in $\mathrm{mm} \times$ bulk density of soil $/ 100 /$ density of water 


\section{Soil sampling and chemical analysis}

Soil samples were air dried, ground and passed to a $2 \mathrm{~mm}$ mesh sieve and subjected to various analyses. Organic carbon was determined by the partial oxidation method (Walkley and Black, 1934). Available nitrogen was determined after $2 \mathrm{M} \mathrm{KCl}$ extractions using UV-VIS spectrophotometer (Systronix model 117, Ahmedabad, India). Extractable phosphorous was determined by the Olson`s extraction method (Jackson, 1973).

\section{Data processing}

Data were statistically analyzed using the SPSS statistical package. Response variables were soil water, nutrients and leaf water status, seedling density (seedlings $\left.\mathrm{m}^{-2}\right)$ and yield of $V$. radiata $\left(\mathrm{g} \mathrm{m}^{-2}\right)$ per replicate. Soil nutrients in September $2003(0-25$ $\mathrm{cm}$ soil layer), leaf water status, seedling density, crop yield and their RNEs were analyzed using a two way ANOVA. Treatment plots and the micro-plots at different distance were the main effects and the difference was the error term. Soil water content data were square root transformed (Sokal and Rohlf, 1981). To test for variation in soil water content in FC and RC plots, three way ANOVAs were performed using soil water data as the dependent variable and treatments, micro-plot distances and soil layers as the main effects and the residual data as the error terms. Since soil sampling for soil water and nutrients in December 2003 was done at one distance only in AC and TC $(1 \mathrm{~m})$ plots, these data were analysed by a two-way ANOVA using treatments (FC, RC, AC and TC plot) and soil depth as the main effect. RNE for soil nutrients in December and soil water was analyzing by two-way ANOVA for each soil layer independently using treatments and micro-plots distances as the main effect. Tree height, collar diameter, diameter at breast height ( $\mathrm{dbh}$ ) and crown diameter was analyzed using a one-way ANOVA. Treatment plots were the main effect. To obtain the relations between crop production and tree growth variables, soil water content and soil nutrients, a Pearson correlation was performed. To obtain homogeneous subsets in treatments, micro-plot distance and soil layers, Duncan Multiple Range Tests (DMRT) were performed for each data set.

\section{Results}

\section{Tree growth variables}

Tree height and crown diameter did not differ $(P>0.05)$ between treatments in both June and December 2003 (Table 1). However, collar diameter differed significantly $(P$ $<0.01)$ at both the time mention above. Diameter at breast height was low $(P<0.05)$ in TC plot in June 2003 but it did not differ $(P>0.05)$ in December 2003. Trees were tallest in FC plots but collar diameter, crown diameter and $\mathrm{DBH}$ were greater in $\mathrm{RC}$ plots. All the growth variables were low in the TC plots. When compared with collar diameter in TC plots, trees were 1.34 and 1.30 fold thicker in FC plots and 1.47 and 1.50 fold thicker in RC plots respectively in June and December 2003. Percent increments in growth variables in December 2003 (over growth in June 2003) were highest in TC plots except of height increment which was highest in RC plots (Table 1). 
Table 1. Mean growth variables and percent growth increment of 114 months old C. mopane trees under agroforestry in dry area of Indian desert

\begin{tabular}{|c|c|c|c|c|c|}
\hline \multirow[t]{2}{*}{ Variables } & \multicolumn{3}{|c|}{ Treatments } & \multicolumn{2}{|c|}{ ANOVA } \\
\hline & FC & $\mathbf{R C}$ & TC & F value & P value \\
\hline \multicolumn{6}{|l|}{ June 2003} \\
\hline Height & $535 \pm 10.4$ & $503 \pm 33.8$ & $476 \pm 4.4$ & 2.01 & NS \\
\hline Collar diameter & $11.9 \pm 0.45$ & $13.1 \pm 0.68$ & $8.9 \pm 0.24$ & 20.12 & 0.002 \\
\hline Crown diameter & $427 \pm 37.1$ & $457 \pm 36.7$ & $408 \pm 17.4$ & 0.59 & NS \\
\hline DBH & $8.6 \pm 0.30$ & $9.6 \pm 0.71$ & $7.4 \pm 0.23$ & 5.51 & 0.044 \\
\hline \multicolumn{6}{|l|}{ December 2003} \\
\hline Height & $540 \pm 11.6$ & $528 \pm 26.8$ & $505 \pm 13.3$ & 1.73 & NS \\
\hline Collar diameter & $12.2 \pm 0.44$ & $13.6 \pm 0.66$ & $9.4 \pm 0.21$ & 20.26 & 0.002 \\
\hline Crown diameter & $437 \pm 37.1$ & $482 \pm 49.4$ & $436 \pm 18.6$ & 0.48 & NS \\
\hline DBH & $8.8 \pm 0.27$ & $10.1 \pm 0.68$ & $8.6 \pm 0.25$ & 3.27 & NS \\
\hline \multicolumn{6}{|c|}{ Per cent growth increment } \\
\hline Height & $0.93 \pm 0.52$ & $5.18 \pm 1.73$ & $4.20 \pm 0.04$ & 4.54 & 0.063 \\
\hline Collar diameter & $2.26 \pm 0.32$ & $2.24 \pm 0.60$ & $6.06 \pm 1.46$ & 4.44 & 0.066 \\
\hline Crown diameter & $2.38 \pm 0.19$ & $5.13 \pm 2.38$ & $6.97 \pm 2.08$ & 1.60 & 0.278 \\
\hline $\mathrm{DBH}$ & $2.75 \pm 0.50$ & $5.67 \pm 0.72$ & $16.24 \pm 2.11$ & 54.29 & 0.000 \\
\hline
\end{tabular}

Values are mean of three replicates $\pm S E$.

$F C$, fixed crop plot $V$. radiata only; $R C$, rotation crop plot in which $V$. radiata was rotated by non-legume crop; and TC, tree crop only.

\section{Above ground resources}

Photosynthetically active radiations (PAR) val. were 264.7, 276.0 and $308.2 \mu \mathrm{mol} \mathrm{m}{ }^{-2}$ $\mathrm{s}^{-1}$ in the canopy zone area ( $1 \mathrm{~m}$ distance from tree trunk) of FC, RC and TC plots, respectively. Whereas PAR values in AC plots (i.e., agriculture crop without trees) was $2282.9 \mu \mathrm{mol} \mathrm{m} \mathrm{m}^{-2} \mathrm{~s}^{-1}$. The reduction in PAR value under the canopy of $C$. mopane trees were $88.4 \%$ in FC plot, $87.9 \%$ in RC plots and $86.5 \%$ in TC plots when compared with PAR value in the AC plots. There was $327.2 \mathrm{~mm}$ rain during July to September with a total number of rainfall days was 26. Main rainfall periods were 6 to $11 \mathrm{July}(121.6 \mathrm{~mm}), 13$ to18 July $(83.1 \mathrm{~mm}), 22$ to 25 July $(19.5 \mathrm{~mm}), 28$ July to $3^{\text {rd }}$ August $(37.1 \mathrm{~mm}), 8$ August $(11.7 \mathrm{~mm}$ ) and 25 to 29 August $2003(52.6 \mathrm{~mm})$ (Fig. 1a). There was only $1.6 \mathrm{~mm}$ rain in September i.e., on 26 September 2003. Total rainfall in year 2003 was $418.7 \mathrm{~mm}$.

\section{Soil water content and dynamics}

Soil water content (SWC) was highest in August 2003 and lowest in December 2003 (Figure $1 b$ ). Two ways ANOVA (treatment $\mathrm{X}$ soil depth) indicated significant $(P<$ $0.01)$ difference due to treatments and soil layers in August, September and December 2003. SWC was highest $(P<0.01)$ in the AC plots (Table 2). In August, AC plot had $101.49 \mathrm{~mm}$ soil water ( $0-75 \mathrm{~cm}$ soil layer) that reduced by $45.42 \%$ in FC, $43.92 \%$ in RC and $36.67 \%$ in TC plots. In September 2003, reduction in SWC was by $38.71 \%$, $36.85 \%$ and $24.43 \%$ in the respective plots as compared to $67.30 \mathrm{~mm}$ in AC plots (Fig. 1b). In December FC and RC plots had $31.51 \%$ and $28.67 \%$ less SWC as compared to $35.19 \mathrm{~mm}$ in AC plots whereas TC plot had $36.9 \%$ low soil water. Average soil water depletion (average of all the four plots) from $18^{\text {th }}$ August to $4^{\text {th }}$ September and $4^{\text {th }}$ September to $3^{\text {rd }}$ December was $18.64 \mathrm{~mm}$ and $23.82 \mathrm{~mm}$, respectively as compared to $69.12 \mathrm{~mm}$ on $18^{\text {th }}$ August 2003. 


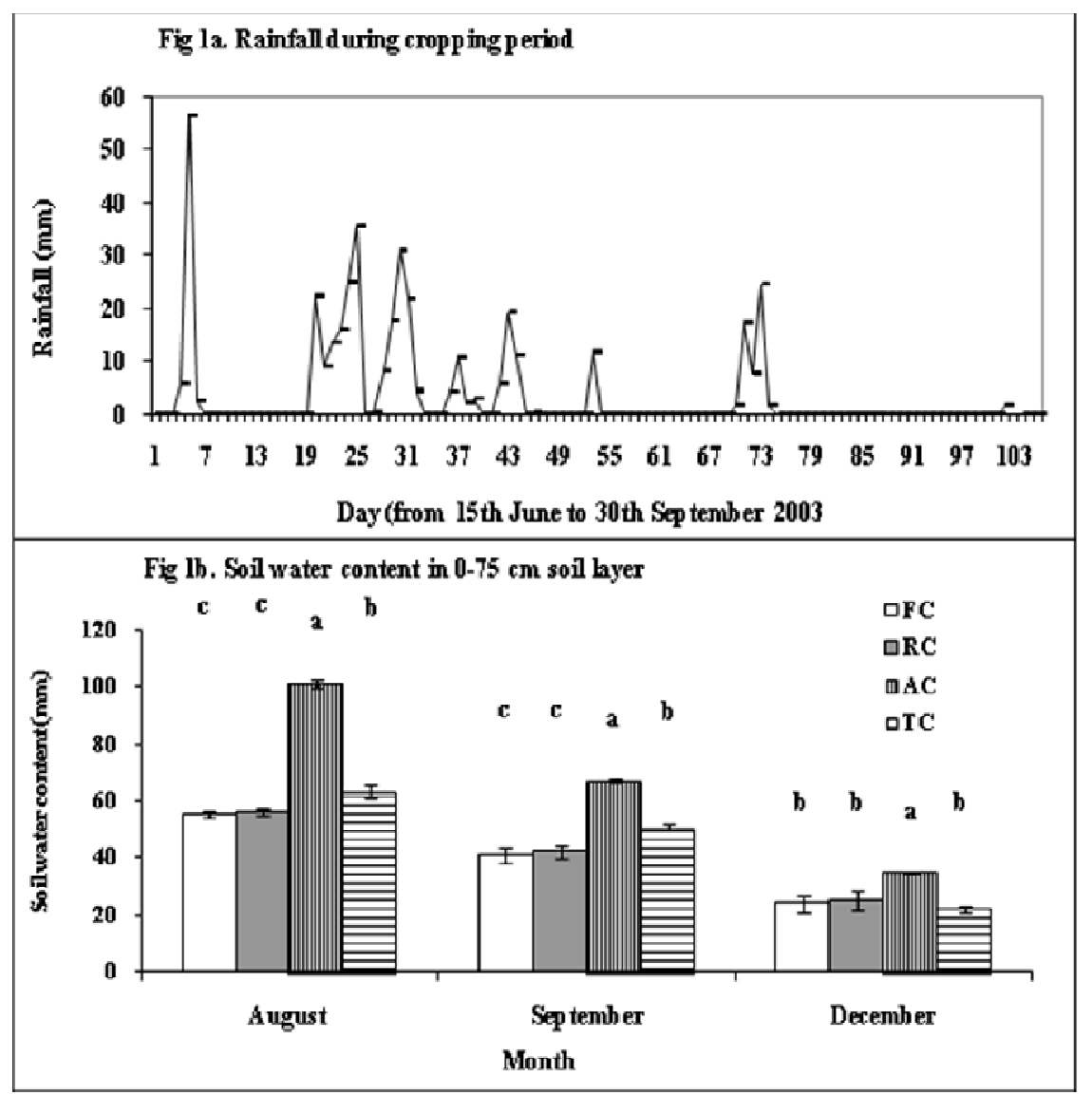

Figure 1. Rainfall distribution and soil water content in $0-75 \mathrm{~cm}$ soil layer. (a), rainfall during 15 June to 30 September 2003; (b), variations in soil water content during monsoon (July to September) and post monsoon period. Non-significantly $(P>0.05)$ different treatments share same letter within month

A three way ANOVA of SWC in FC and RC plots data did not differ $(P>0.05)$ between treatments (Table 2). SWC differed $(P<0.01)$ between soil layers but did not vary in micro-plots at different distance in August 2003, whereas in September and December 2003, the variation due to soil layers was not significant but SWC differed $(P$ $<0.01)$ due to distances (micro-plots). SWC was lowest near tree but $2.5 \mathrm{~m}$ (middle) and $3.5 \mathrm{~m}$ (centre) distances did not differ in SWC in September 2003 but all the distances (micro-plots) indicated significant difference in December 2003. Considering the soil depth, SWC was lowest in 0-25 cm soil layer and increased with soil depth. SWC was lowest in 0-25 cm in August, $25-50 \mathrm{~cm}$ in September and 50-75 cm soil layer in December 2003 (Figure 2). All the interaction terms indicated non-significant values. 
Table 2. Effect of Colophospermum mopane trees on soil water status (\%, w/w) during crop growing (August and September 2003) and crop harvesting (December 2003) period

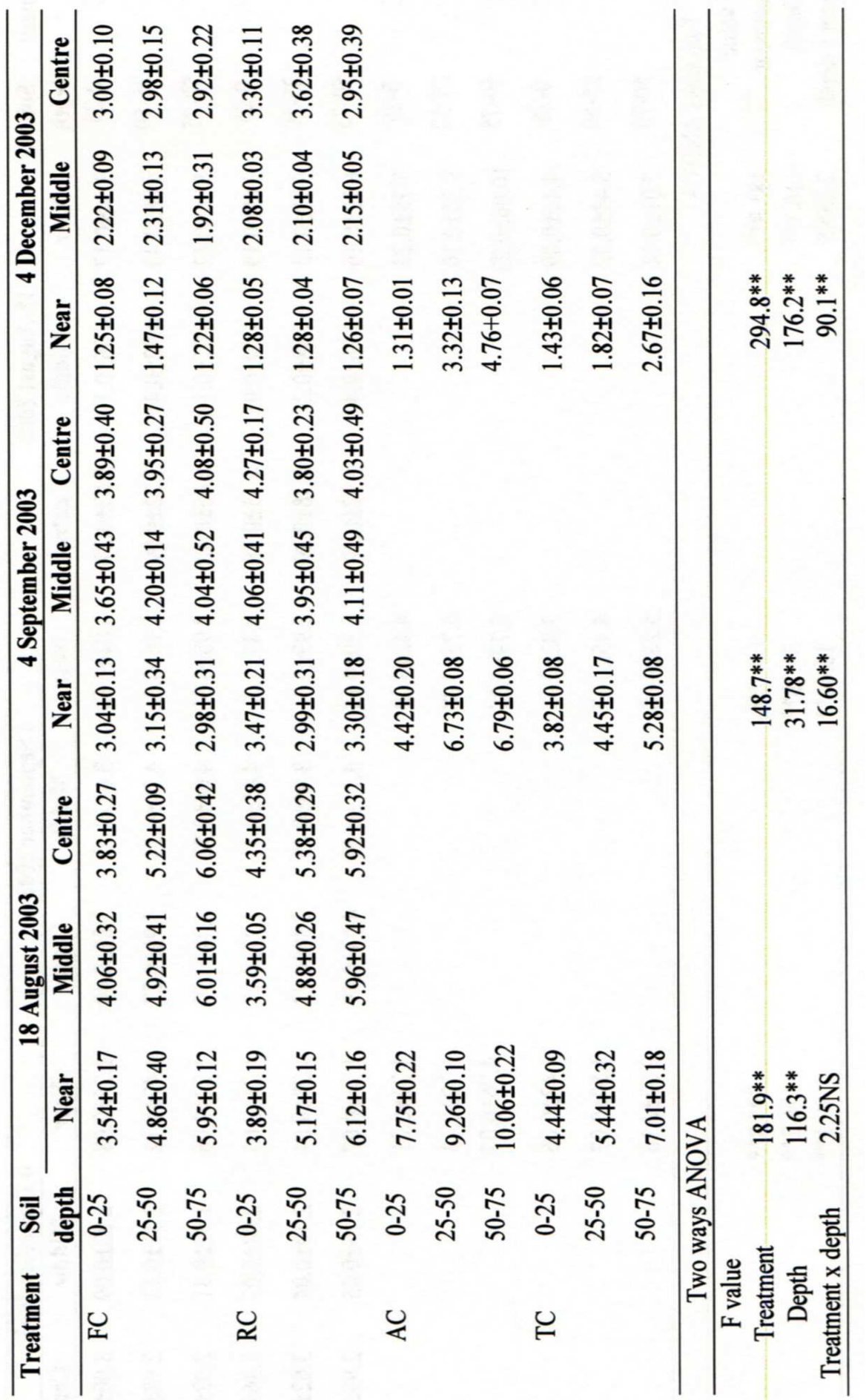

Values are mean of three replicates $\pm S E$.

$F C$, fixed crop of $V$. radiata only; $R C$, rotation crop in which $V$. radiata was rotated by nonlegume crop; AC, sole agriculture crop; and TC, tree crop only. 


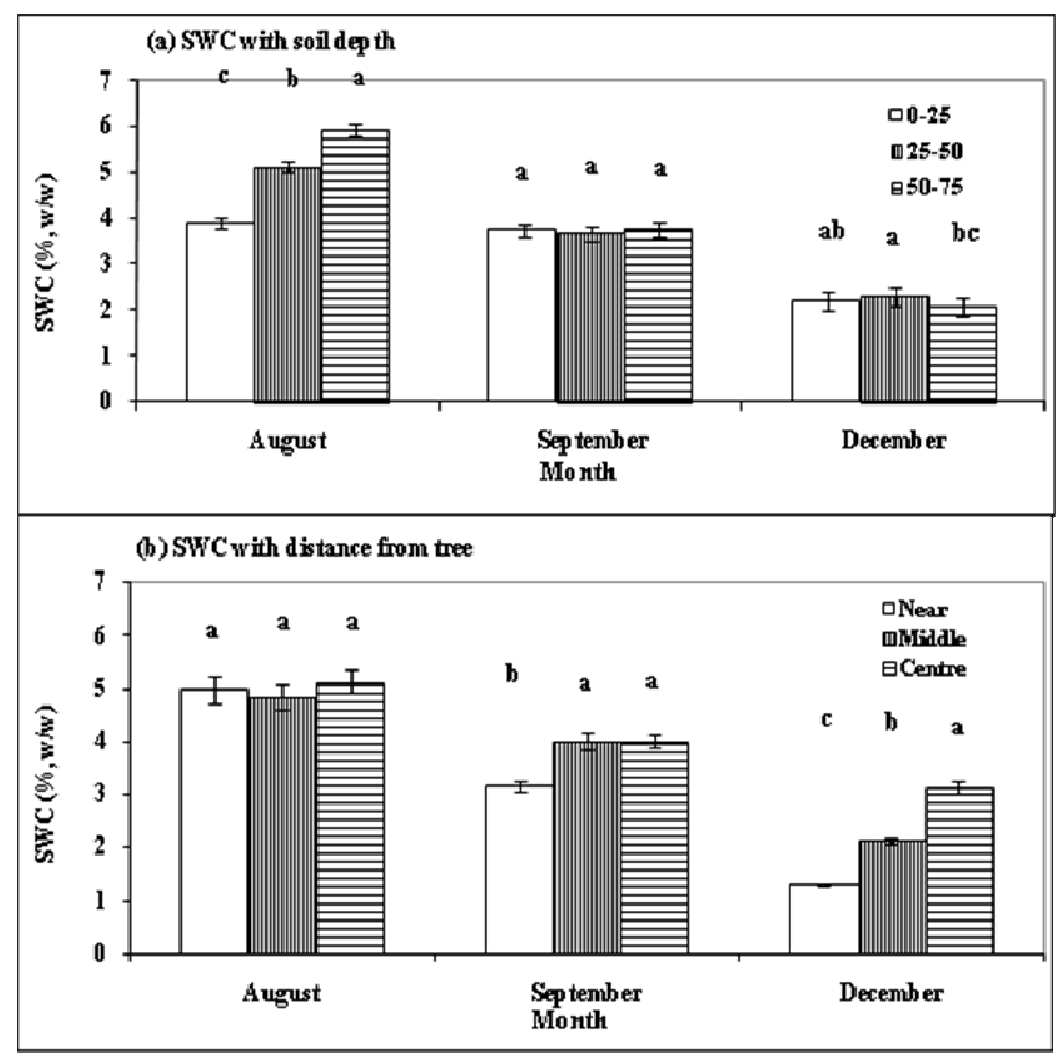

Figure 2. Changes in soil water content with time in different soil layers and distance from $C$. mopane tree. (a), variations with soil depth (mean of treatments FC and RC and distance); (b) variations with soil depth (mean of treatments $F C$ and $R C$ and soil depth). Error bars are $\pm S E$ of three replications. Bars with similar alphabets did not differ significantly $(P>0.05)$

\section{Soil nutrients}

Soil organic matter $(\mathrm{SOM})$, available $\mathrm{PO}_{4}-\mathrm{P}, \mathrm{NH}_{4}-\mathrm{N}$ and $\mathrm{NO}_{3}-\mathrm{N}$ of $0-25 \mathrm{~cm}$ soil layers in September and December 2003 did not differ between the treatments as well as the sampling position (near, middle, and center). However, available $\mathrm{NO}_{3}-\mathrm{N}$ indicated low $(P<0.05)$ value at center whereas middle and center micro-plots did not differ in $\mathrm{NO}_{3}-\mathrm{N}$ concentration. These nutrients decreased in December 2003 than in September 2003 in all the plots except in $\mathrm{AC}$, in which there was an increase in $\mathrm{NH}_{4}-\mathrm{N}$ and $\mathrm{NO}_{3}-\mathrm{N}$ (Fig. 3). In December 2003, SOM, $\mathrm{PO}_{4}-\mathrm{P}$ and $\mathrm{NO}_{3}-\mathrm{N}$ did not differ due to treatments. But DMRT indicated low $(P<0.05)$ availability of $\mathrm{PO}_{4}-\mathrm{P}$ and $\mathrm{NO}_{3}-\mathrm{N}$ in TC and $\mathrm{FC}$ plots, respectively whereas $\mathrm{NH}_{4}-\mathrm{N}$ was lowest $(P<0.01)$ in $\mathrm{TC}$ and highest in AC plots (Table 3). These soil nutrients were highest $(P<0.01)$ in availability in $0-25 \mathrm{~cm}$ but did not differ between $25-50 \mathrm{~cm}$ and $50-75 \mathrm{~cm}$ soil layers except for $\mathrm{NH}_{4}-\mathrm{N}$.

Three ways ANOVA of these nutrients for FC and RC plots indicated no variations due to treatment and distance from tree (Table 3). But the soil nutrients were highest $(P<$ $0.05)$ in $0-25 \mathrm{~cm}$ soil layer. Duncan Multiple Range Test (DMRT) indicated greater $(P$ $<0.05)$ availability of SOM (mean of soil depths and treatments) near tree. $\mathrm{NH}_{4}-\mathrm{N}$ increased with distance and highest concentration was at centre. $\mathrm{NO}_{3}-\mathrm{N}$ was highest at centre and lowest at middle while $\mathrm{PO}_{4}-\mathrm{P}$ was highest at middle and lowest at centre of four trees. All the interaction terms were not significant $(P>0.05)$. 
Table 3. Effect of Colophospermum mopane trees on soil nutrients in December 2003 (After crop harvesting)

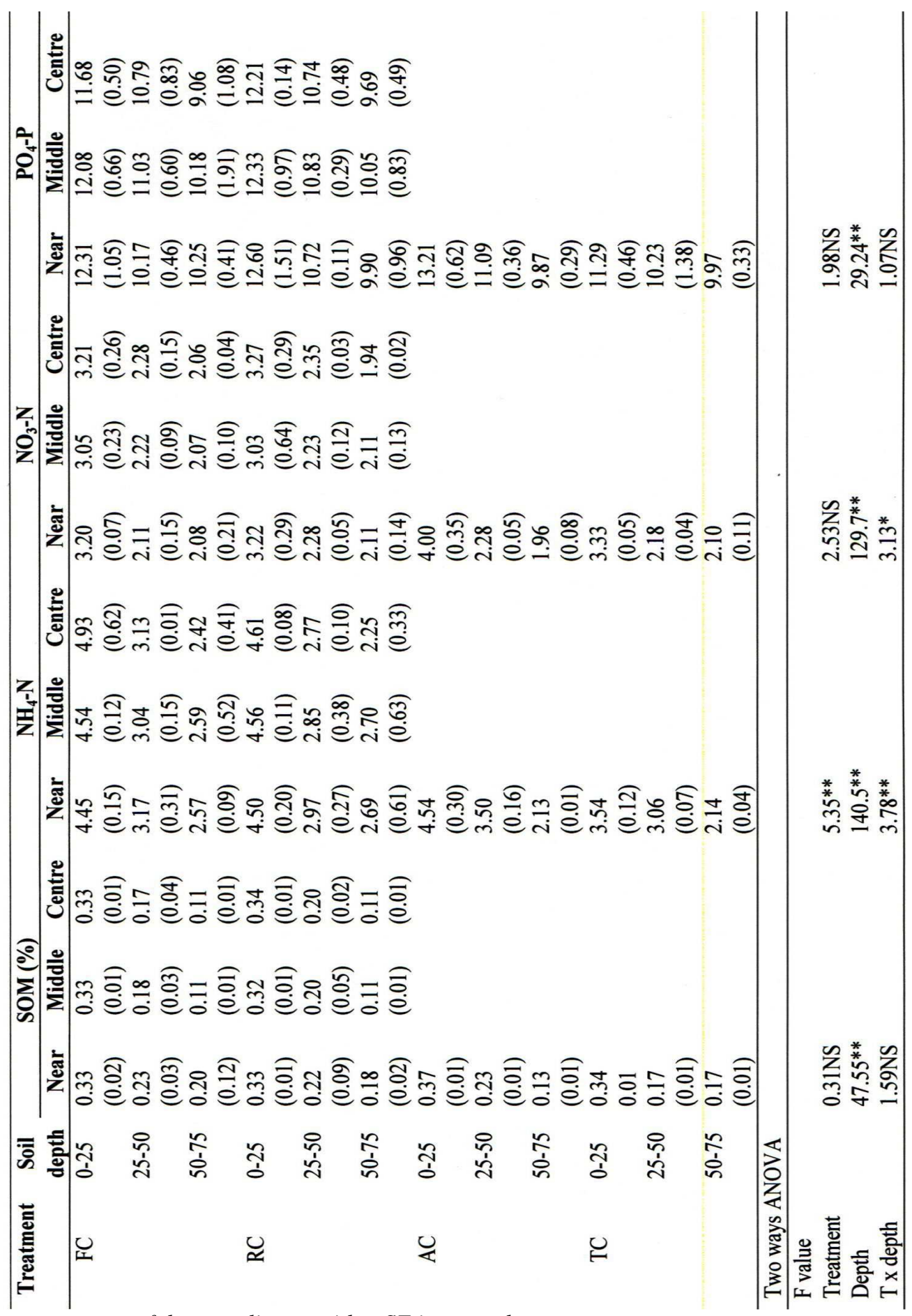

Values are mean of three replicates with $\pm S E$ in parentheses.

Treatments as in Table 3.

Three way ANOVA for FC and RC plots was not significant except for soil layers. 
Table 4. Effect of over canopy tree on density of germinated seedlings and leaf water status of Vigna radiata in post dawn (14.00 hr) period

\begin{tabular}{|c|c|c|c|c|}
\hline \multirow[t]{2}{*}{ Treatment } & \multirow[t]{2}{*}{ Distance } & \multirow{2}{*}{$\begin{array}{l}\text { Seedling density } \\
\left(\text { no. } \mathbf{m}^{-2}\right)\end{array}$} & \multicolumn{2}{|c|}{ Leaf water status at $14.00 \mathrm{hr}(\%)$} \\
\hline & & & 8 September 2003 & 16 September 2003 \\
\hline \multirow[t]{4}{*}{$\mathrm{FC}$} & Near & $3.67 \pm 0.88 \mathrm{a}$ & $73.57 \pm 0.20 \mathrm{a}$ & $71.81 \pm 0.33 \mathrm{a}$ \\
\hline & Middle & $6.67 \pm 0.88 b$ & $72.50 \pm 0.12 b$ & $70.54 \pm 0.24 b$ \\
\hline & Centre & $7.00 \pm 0.58 b$ & $70.53 \pm 0.13 c$ & $69.54 \pm 0.13 c$ \\
\hline & Mean & $5.78+0.66$ & $72.20 \pm 0.45$ & $70.63 \pm 0.35$ \\
\hline \multirow[t]{4}{*}{$\mathrm{RC}$} & Near & $3.67 \pm 0.33 \mathrm{a}$ & $73.20 \pm 0.11 \mathrm{a}$ & $71.18 \pm 0.12 \mathrm{a}$ \\
\hline & Middle & $4.67 \pm 0.33 b$ & $72.38 \pm 0.11 b$ & $70.58 \pm 0.26 b$ \\
\hline & Centre & $6.00 \pm 0.01 b$ & $70.88 \pm 0.07 \mathrm{c}$ & $70.25 \pm 0.22 c$ \\
\hline & Mean & $4.78+0.36$ & $72.15 \pm 0.34$ & $70.69 \pm 0.17$ \\
\hline $\mathrm{AC}$ & & $34.67 \pm 0.33$ & $66.01 \pm 0.31$ & $66.35 \pm 0.23$ \\
\hline \multirow{2}{*}{\multicolumn{5}{|c|}{$\begin{array}{l}\text { Two way ANOVA for FC and RC plots } \\
\text { Probability of F value }\end{array}$}} \\
\hline & & & & \\
\hline & Treatment & 4.26 & 0.23 & 0.051 \\
\hline & Distance & $12.05^{*}$ & $221.99 * *$ & $24.85 * *$ \\
\hline & $\mathrm{T} \times \mathrm{D}$ & 1.42 & $4.06 *$ & $4.36^{*}$ \\
\hline
\end{tabular}

Values are mean of three replicates \pm SE. Treatments as in Table 2.

*, significant at $P<0.05$; **, significant at $P<0.01$.

\section{Density and leaf water status of $V$. radiata}

Effect of trees on seedling population of $V$. radiata was observed since the time of germination. Density of germinated seedlings was higher $(P<0.01)$ in the AC plots $\left(34.67 \mathrm{~m}^{-2}\right)$ as compared to the FC $\left(5.78 \mathrm{~m}^{-2}\right)$ and $\mathrm{RC}\left(4.78 \mathrm{~m}^{-2}\right)$ plots (Table 4). Twoway ANOVA indicated no difference in seedling population between FC and RC plots (though population was relatively greater in FC plots than in RC plots) but density was less $(P<0.01)$ near tree and increased with distance being highest at centre, which did not differ with population at middle micro-plot $(2.5 \mathrm{~m}$, DMRT). Leaf water status (LWS) was higher on $8^{\text {th }}$ September 2003 as compared to $16^{\text {th }}$ September 2003 (Table $4)$. It was lowest $(P<0.01)$ in AC plots but it did not differ between FC and RC plots. In FC and RC plots LWS was highest $(P<0.05)$ at $1 \mathrm{~m}(71.5 \%)$ and decreased with increase in distance from tree $(69.9 \%$ at centre $)$.

\section{Yield of $V$. radiata}

Total yield (grain + husk + holm) of V. radiata was 95.61, 99.00 and $573.00 \mathrm{~g} \mathrm{~m}^{-2}$ in FC, RC and AC plots, respectively (Table 5). When compared with yield in AC plots, reduction in crop yield was by $83.3 \%$ in FC and $82.7 \%$ in RC plots. Grain yield reduced by $97.5 \%$ in FC and $97.3 \%$ in RC plots, whereas the husk and holm reduced by $91.3 \%$ and $74.9 \%$ in FC plots and $90.6 \%$ and $74.1 \%$ in RC plots, respectively than in AC plots. Two ways ANOVA indicated no difference in treatments (FC and RC plots) and distance from tree for husk, grain and holm yield. However, these crop yield variables were relatively low at $1 \mathrm{~m}$ and highest at center. Per cent contribution of husk, grain and holm to the total produce was $12.6 \%, 28.3 \%$ and $59.1 \%$, respectively in AC plots. Average (mean of distance) contribution was $6.6 \%, 4.3 \%$ and $89.1 \%$ in FC and $6.9 \%, 4.4 \%$ and $88.7 \%$ in RC plots, respectively for husk, grain and holm. Reduction in grain yield was relatively greater (from $28.3 \%$ in $\mathrm{AC}$ to $4.4 \%$ in FC/RC) as compared to husk (12.6\% in AC to $6.8 \%$ in FC/RC). Percent contribution of husk and grain to the total yield increased with distance from tree and were highest at the centre of four trees (Table 5). 
Table 5. Effect of over canopy of $C$. mopane on average yield $\left(\mathrm{g} \mathrm{m}^{-2}\right)$ of $V$. radiata

\begin{tabular}{|c|c|c|c|c|c|}
\hline Treatment & Distance & Husk & Grain & Holm & Total \\
\hline \multirow[t]{4}{*}{$\mathrm{FC}$} & Near & $5.67 \pm 1.01 \mathrm{a}$ & $3.67 \pm 0.93 a$ & $78.00 \pm 8.32 \mathrm{c}$ & $87.33 \pm 10.24 c$ \\
\hline & Middle & $6.00 \pm 1.15 \mathrm{a}$ & $4.00 \pm 1.04 \mathrm{a}$ & $83.67 \pm 6.50 b c$ & $93.67 \pm 8.67 b c$ \\
\hline & Centre & $7.33 \pm 1.31 \mathrm{a}$ & $4.67 \pm 0.93 a$ & $93.83 \pm 3.60 \mathrm{ab}$ & $105.83 \pm 5.78 \mathrm{ab}$ \\
\hline & Mean & $6.33 \pm 0.63$ & $4.11 \pm 0.51$ & $85.17 \pm 3.97$ & $95.61 \pm 5.01$ \\
\hline \multirow[t]{4}{*}{$\mathrm{RC}$} & Near & $5.83 \pm 0.88 \mathrm{a}$ & $3.50 \pm 0.58 \mathrm{a}$ & $79.50 \pm 7.40 \mathrm{c}$ & $88.83 \pm 8.85 c$ \\
\hline & Middle & $6.33 \pm 1.30 \mathrm{a}$ & $4.33 \pm 1.09 \mathrm{a}$ & $87.00 \pm 9.64 b c$ & $97.67 \pm 11.98 b c$ \\
\hline & Centre & $8.33 \pm 0.93 a$ & $5.33 \pm 0.88 \mathrm{a}$ & $96.83 \pm 5.36 \mathrm{ab}$ & $110.50 \pm 7.08 \mathrm{ab}$ \\
\hline & Mean & $6.83 \pm 0.65$ & $4.39 \pm 0.51$ & $87.78 \pm 4.58$ & $99.00 \pm 5.71$ \\
\hline $\mathrm{AC}^{*}$ & & $72.3 \pm 7.80$ & $162.0 \pm 4.48$ & $338.7 \pm 29.2$ & $573.0 \pm 19.9$ \\
\hline \multicolumn{6}{|c|}{ Two way ANOVA for FC and RC plots } \\
\hline & Treatment & 0.305 & 0.136 & 0.204 & 0.220 \\
\hline & Distance & 1.974 & 1.190 & 2.780 & 2.695 \\
\hline & $\Gamma \times D$ & 0.079 & 0.103 & 0.010 & 0.012 \\
\hline
\end{tabular}

Values are mean of three replicates with \pm SE. Treatments as in Table 2.

One-way ANOVA indicated significant $(P<0.01)$ difference among $F C, R C$ and AC plots.

Within each column, treatments which are not-significantly different share the same letter.

\section{Correlations in soil resources, tree growth variables and crop yield}

Tree height, collar diameter and crown diameter were negatively correlated with SWC in August, September (0-25 and 25-50 cm soil layers) and December 2003 (50-75 $\mathrm{cm}$ soil layer), soil nutrients and crop yield i.e., husk $(r=-0.917$ to $-0.971, P<0.01)$, grain $(r=-0.0 .933$ to $-0.988, P<0.01)$ and holm $(r=-0.939$ to $-0.969, P<0.01)$ (Table $6)$. A negative correlation was also observed between tree growth and density of $V$. radiata seedlings. However, growth variable were positively correlated SWC in 0-25 $\mathrm{cm}$ soil layer in December and $\mathrm{SOM}$ and $\mathrm{NH}_{4}-\mathrm{N}$ in September 2003, and leaf water status of $V$. radiata. Density and yield of $V$. radiata were positively correlated with SWC in all the soil layer in August and 25-50 and 50-75 cm soil layer in September 2003. But crop yield was negatively correlated with SOM $(r=-0.477$ to $-0.592, P<$ $0.01)$ and $\mathrm{NH}_{4}-\mathrm{N}(r=-0.672$ to $-0.713, P<0.01)$ and positively related with $\mathrm{PO}_{4}-\mathrm{P}(r=$ 0.904 to $0.934, P<0.01)$ and $\mathrm{NO}_{3}-\mathrm{N}(r=0.908$ to $0.955, P<0.01, \mathrm{n}=21)$. Availability of SOM and $\mathrm{NH}_{4}-\mathrm{N}$ was negatively related with $\mathrm{SWC}$ in $25-50$ and $50-75 \mathrm{~cm}$ soil layer in September 2003 in but reverse trend was observed in December 2003. $\mathrm{PO}_{4}-\mathrm{P}$ and $\mathrm{NO}_{3}-\mathrm{N}$ were positively related with SWC in September 2003 and December 2003 (Table 6).

\section{Relative neighbour effects}

Relative neighbour effects (RNE) values for soil water (RNESWC) was positive except for 0-25 cm soil layer of middle and center micro-plots in December 2003 (Figure $3 a$ ). In August it was highest in $0-25 \mathrm{~cm}$ soil layer whereas $\mathrm{RNE}_{\mathrm{SWC}}$ was highest in 25-50 cm and 50-75 cm soil layers, respectively in September and December 2003. $\mathrm{RNE}_{\text {Nutrient }}$ was positive for most of the soil nutrients except for $\mathrm{SOM}$ and $\mathrm{NH}_{4}-\mathrm{N}$ in September 2003. $\mathrm{RNE}_{\text {Nutrient }}$ was also positive for $\mathrm{SOM}$ and $\mathrm{PO}_{4}-\mathrm{P}$ in $50-75 \mathrm{~cm}$ (near tree), $\mathrm{NH}_{4}-\mathrm{N}$ in $0-25 \mathrm{~cm}$ (middle and center of four trees) and $50-75 \mathrm{~cm}$ soil layers and $\mathrm{NO}_{3}-\mathrm{N}$ in 50-75 $\mathrm{cm}$ soil layers (Figure $3 b$ ). RNE was also positive for density of $V$. radiata and crop yield like grain, holm and the total crop yield (Figure $3 \mathrm{c}$ ). The values were higher near the tress as compared to middle and center of four trees. However, 
$\mathrm{RNE}_{\mathrm{LWS}}$ for $V$. radiata leaves was negative at all the three distances with lowest (more negative) value near the trees.

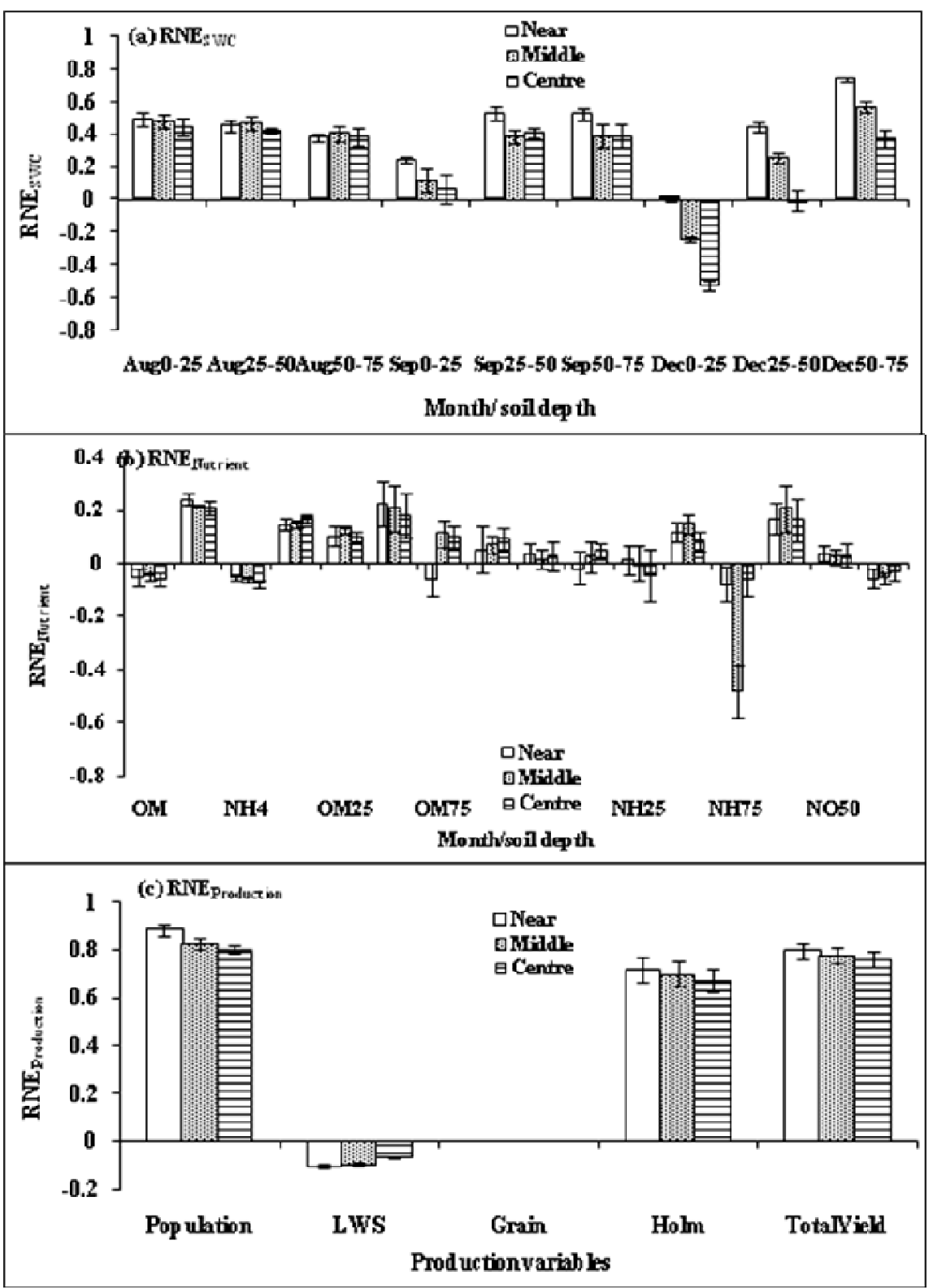

Figure 3. Relative neighbour effects of $C$. mopane on (a), soil water content; (b), soil nutrients; and crop growth and yield parameters. LWS, leaf water status of V. radiata seedlings on 8 and 16 September 2003. Error bars are $\pm S E$ of three replications. Bars with similar alphabets did not differ significantly $(P>0.05)$ within the groups 
Table 6. Correlation coefficient of tree growth variables of December 2003, soil resources and crop production

\begin{tabular}{|c|c|c|c|c|c|c|c|}
\hline Variables & Height & Crown dia. & Collar dia. & $\mathbf{A} \mathbf{U} \mathbf{G}_{\mathbf{S W C}}$ & SEP $_{\text {SWC25 }}$ & SEP $_{\text {SWC50 }}$ & SEP $_{\text {SWC75 }}$ \\
\hline $\mathrm{AUG}_{\mathrm{SWC}}$ & $-0.929 * *$ & $-0.913 * *$ & $-0.907 * *$ & - & $0.446^{*}$ & $0.845 * *$ & $0.763 * *$ \\
\hline $\mathrm{SEP}_{\mathrm{SWC} 25}$ & -0.374 & $-0.461^{*}$ & -0.353 & $0.446^{*}$ & - & - & - \\
\hline $\mathrm{SEP}_{\text {SWC50 }}$ & $-0.836 * *$ & $-0.876 * *$ & $-0.893 * *$ & $0.845 * *$ & - & - & - \\
\hline $\mathrm{SEP}_{\text {SWC75 }}$ & $-0.770 * *$ & $-0.750 * *$ & $-0.819 * *$ & $0.763 * *$ & - & - & - \\
\hline $\mathrm{DEC}_{\text {SWC } 25}$ & 0.352 & 0.316 & $0.406^{*}$ & 0.289 & 0.329 & -0.137 & -0.174 \\
\hline $\mathrm{DEC}_{\text {SWC50 }}$ & -0.397 & -0.399 & -0.351 & $0.439^{*}$ & $0.615^{* *}$ & $0.529 * *$ & $0.406 *$ \\
\hline $\mathrm{DEC}_{\text {SWC75 }}$ & $-0.787 * *$ & $-0.717 * *$ & $-0.738 * *$ & $0.776 * *$ & $0.551 * *$ & $0.814 * *$ & $0.809 * *$ \\
\hline $\mathrm{SEP}_{\mathrm{SOM}}$ & $0.564 * *$ & $0.536^{*}$ & $0.580 * *$ & $0.485^{*}$ & -0.370 & $-0.523 *$ & $-0.638 * *$ \\
\hline $\mathrm{SEP}_{\mathrm{PO} 4-\mathrm{P}}$ & $-0.925 * *$ & $-0.906 * *$ & $-0.957 * *$ & $0.898 * *$ & $0.476^{*}$ & $0.915 * *$ & $0.854 * *$ \\
\hline $\mathrm{SEP}_{\mathrm{NH} 4-\mathrm{N}}$ & $0.731 * *$ & $0.621 * *$ & $0.751 * *$ & $-0.626 * *$ & 0.154 & $-0.548 *$ & $-0.514 *$ \\
\hline $\mathrm{SEP}_{\mathrm{NO} 3-\mathrm{N}}$ & $-0.924 * *$ & $-0.938 * *$ & $-0.937 * *$ & $0.914 * *$ & 0.267 & $0.835^{* *}$ & $0.754 * *$ \\
\hline $\mathrm{DEC}_{\text {SOM} 25}$ & $-0.695 * *$ & $-0.761 * *$ & $-0.767 * *$ & - & $-0.182 \mathrm{a}$ & $0.396 \mathrm{~b}$ & $0.630 * *_{\mathrm{c}}$ \\
\hline $\mathrm{DEC}_{\text {SOM50 }}$ & $-0.495^{*}$ & -0.356 & $-0.450^{*}$ & - & $0.019 \mathrm{a}$ & $0.392 b$ & $0.387 \mathrm{c}$ \\
\hline $\mathrm{DEC}_{\mathrm{PO} 4-\mathrm{P} 25}$ & $-0.405^{*}$ & -0.290 & -0.305 & - & $-0.211 \mathrm{a}$ & $0.100 \mathrm{~b}$ & $0.167 \mathrm{c}$ \\
\hline $\mathrm{DEC}_{\mathrm{NH} 4-\mathrm{N} 50}$ & $-0.470^{*}$ & $-0.575^{* *}$ & $-0.520 * *$ & - & $-0.003 a$ & $0.473 * b$ & $0.461{ }^{*} \mathrm{c}$ \\
\hline $\mathrm{DEC}_{\mathrm{NO} 3-\mathrm{N} 25}$ & $-0.674 * *$ & $-0.519 * *$ & $-0.582 * *$ & - & $-0.213 \mathrm{a}$ & $0.293 b$ & $0.551 * * \mathrm{c}$ \\
\hline Population & $-0.978 * *$ & $-0.924 * *$ & $-0.981 * *$ & $0.947 * *$ & 0.432 & $0.918 * *$ & $0.864 * *$ \\
\hline LWS & $0.888 * *$ & $0.836 * *$ & $0.880^{* *}$ & $-0.872 * *$ & $-534 * *$ & $-0.881 * *$ & $-0.869 * *$ \\
\hline Grain yield & $-0.988 * *$ & $-0.933 * *$ & $-0.973 * *$ & $0.956 * *$ & 0.390 & $0.875^{* *}$ & $0.830 * *$ \\
\hline Holm yield & $-0.979 * *$ & $-0.950 * *$ & $-0.917 * *$ & $0.964 * *$ & 0.396 & $0.863 * *$ & $0.828 * *$ \\
\hline Total yield & $-0.985 * *$ & $-0.961 * *$ & $-0.925^{* *}$ & $0.955 * *$ & 0.396 & $0.870 * *$ & $0.831 * *$ \\
\hline
\end{tabular}

Significant at $* ; P<0.05$ and $* * ; P<0.01$. The values without $*$ are not significant.

SWC, soil water content. 25, 0-25 cm; 50, 25-50 cm; and 75, 50-75 cm soil layers; LWS, leaf water status of $V$. radiata crop.

$a, b$ and c, correlation co-efficient in relation to SWC in December 2003 in 0-25, 25-50 and 50-75 cm soil layers, respectively.

\section{Discussion}

Interaction between tree and the associated crop for growth resources like light, water and nutrients affects the overall productivity of the system (Belsky et al. 1993). However, the types of interactions depended upon the competitive (Inchausti, 1995), and facilitative (Greenlee and Callaway, 1996) processes (i.e., shading and nutrient enrichment) of the associated trees. Taller and thicker tree in the FC and RC plot as compared to the trees in TC plots were due to soil working in the cropping plots. But greater incremental growth in trees of TC plots as compared to that in the FC and RC plots were due to greater availability of soil water discussed in next sections.

\section{Soil water content}

Differences in growth variables of $C$. mopane trees influenced the availability of soil water and nutrients. A negative correlation between tree growth variables and soil water contents (SWC) showing greater soil water use in tree-integrated plots, particularly by tree as compared to sole agriculture plot. Non-significant difference in SWC due to distance (micro-plots) in August 2003 was due to availability of sufficient amount of water received through rain in July and August. However, low soil water in 0-25 cm soil layer was due to utilization by tree and agriculture crop (Figure 2), though reduction in SWC in this soil layer through surface evaporation cannot be ruled out (Gibson and Bachelard, 1986). Significantly low SWC near tree zone (1m distance from tree) in September was due to soil water use by tree (Table 2). Relatively low input of water through rain between 18 August and 4 September (Figure 1) and high water use by tree in the rooting zone made a gradient in SWC, which increased with distance from tree 
trunk. However, relatively low SWC in 25-50 cm soil layer in September 2003 indicated that tree and probably $V$. radiata used soil water from this soil layer. Variations in SWC became more evident in December 2003 when it was highest $(P<$ 0.01 ) at center of four trees suggesting greater amount of soil water extraction by trees from near and middle distances. A decrease in SWC in 50-75 cm soil layer in December 2003 was indicative of soil water use from this layer. This suggests that $C$. mopane utilize soil water from topsoil layer during sufficient soil water availability whereas it utilizes deeper soil water when soil water stress prevails in upper soil layers. Competition for soil water during August and September (crop growing period) might cause reduction in crop yield. Relatively greater positive $\mathrm{RNE}_{\mathrm{SWC}}$ in $0-25 \mathrm{~cm}$ in August, in 50-75 cm in September and 50-75 cm soil layer in December 2003 as compared to the other soil layers also indicated competition for soil water use in these layers (Figure $3 a$ ). A facilitative effect (negative $\mathrm{RNE}_{\mathrm{SWC}}$ ) of $C$. mopane trees at middle and center of four trees in 0-25 cm soil layer in December 2003 was probably due to 'hydraulic lift' in which tree extracted water from deeper soil layer and redistribute it in the upper soil layer. Fuentes et al. (1984) also recorded an increase in soil water availability as a result of facilitative influence of neighbours. Competition for water and nutrients indicated overlapping of fibrous roots of $C$. mopane trees and crop as observed in other studies (Singh and Rathod, 2002; Wallace et al., 1980). Positive interactions found to increase with stress as evidenced by decreased $\mathrm{RNE}_{S W C}$ in 0-25 cm soil layer in December 2003 as compared to that in September 2003 (Figure 1a), which was comparatively wetter (Callaway et al., 2002).

\section{Soil nutrients}

The mechanism in building up of the soil nutrient level is the improvement of soil organic matter and other nutrients through addition of litter by the trees and associated vegetation and turnover of roots. Significantly higher $\mathrm{SOM}, \mathrm{PO}_{4}-\mathrm{P}, \mathrm{NH}_{4}-\mathrm{N}$ and $\mathrm{NO}_{3}-\mathrm{N}$ in upper $0-25 \mathrm{~cm}$ as compared to $25-50$ and $50-75 \mathrm{~cm}$ soil layers was attributed to be due to greater accumulation of organic matter on the surface of the soil through litter addition (Table 3). Litter addition and soil water availability regulate the organic matter decomposition and the formation of stable and labile soil organic matter pools (Vitousek and Sanford, 1986). This is evidenced by significantly $(P<0.05)$ greater availability of SOM (mean of soil depths and treatments) near tree. Though not significant but lowest availability $\mathrm{PO}_{4}-\mathrm{P}, \mathrm{NH}_{4}-\mathrm{N}$ and $\mathrm{NO}_{3}-\mathrm{N}(P<0.05)$ near tree as compared to the middle and center of four trees distances was due to their utilization in tree/ crop growth (Table 3). Browald (1987) also observed higher concentration of $\mathrm{NH}_{4}-\mathrm{N}$ and lower concentration of $\mathrm{NO}_{3}-\mathrm{N}$ at closer distance of trees indicating an efficient uptake of nitrate and enhanced mineralization closer to trees. Low $(P<0.05$, DMRT) availability of $\mathrm{NO}_{3}-\mathrm{N}$ and $\mathrm{PO}_{4}-\mathrm{P}$ in TC and $\mathrm{FC}$ plots was due to utilization by trees. Lowest $(P<$ 0.01 ) availability of $\mathrm{NH}_{4}-\mathrm{N}$ in $\mathrm{TC}$ and highest in $\mathrm{AC}$ plots was due to nitrogen addition through nitrogen fixing by $V$. radiata, a legume crop. Relatively low nutrient concentration in December 2003 as compared to that in September 2003 was resulted from their utilization in tree/ crop growth. Positive RNE values for most of the nutrients indicated competitive effect of $C$. mopane trees for utilizing soil nutrients. However a few negative RNE values near tree in 50-75 cm soil layer for $S O M$ and $\mathrm{PO}_{4}-\mathrm{P}, 0-25$ and $50-75 \mathrm{~cm}$ soil layer for $\mathrm{NH}_{4}-\mathrm{N}$ and $50-75 \mathrm{~cm}$ soil layer for $\mathrm{NO}_{3}-\mathrm{N}$ indicated facilitative effect of $C$. mopane trees for these nutrients (Figure $3 b$ ), which was due to added litters or root turn over. 


\section{Light resource and leaf water status}

Reduction in PAR under the canopy of C. mopane by $88.4 \%$ in FC to $86.5 \%$ in TC plots indicated a dense canopy influencing transpiration losses of the under canopy crop. That affected water status of $V$. radiata seedling growing in the vicinity of the trees. Significantly higher level of leaf water status in $V$. radiata leaves in tree integrated plots (FC and RC plots) as compared to that in AC plot suggested a reduction in transpiration loss of agriculture crop resulted from reduced PAR. Greater was the tree size higher was the leaf water status (Table $4 \& 6$ ). A negative $\mathrm{RNE}_{\mathrm{Lws}}$ indicated facilitative effects of $C$. mopane tree by increasing water status of the associated crops (Fig. 3c). A decreased PAR and increased productivity under canopy of savanna trees is the most common pattern in tropical tree communities with low density, low rainfall and moderate soil fertility sites (Belsky et al., 1993).

\section{Yield of V. radiata}

Significantly low density of $V$. radiata plants on 22 August 2003 in tree-integrated plots (FC, $5.78 \mathrm{~m}^{-2}$ and $\mathrm{RC}, 4.78 \mathrm{~m}^{-2}$ ) as compared to sole crop plot (AC, $34.67 \mathrm{~m}^{-2}$ ) indicated a tree-influenced reduction in crop population. A dry spell of 15 days (from date of crop sowing on 21 June 2003) probably caused a reduction in soil water in FC and RC plots due to use of water by trees affecting germination, population and growth of $V$. radiata seedlings (personal observation). Reduced growth and population of vegetation have been recorded in other deserts (Franco and Nobel, 1989), drought affected fields (Wilson and Tilman, 1991) and in alpine vegetation (Wilson, 1993). Inouye et al. (1980) also reported that the competition among annual plants of the Sonoran Desert did not affect survival but reduced growth rate, biomass and fecundity.

Low yield of $V$. radiata in FC and RC was attributable to reduction in soil resources particularly soil water (Table $2 \& 5$ ) discussed earlier. Significantly high yield of $V$. radiata in AC plots suggested sufficient soil water and nutrient availability enhancing crop yield. A positive correlation between soil water content and crop yield suggested greater availability of soil water in AC plot as compared to that in FC and RC plots. Though not significant but increase in grain, husk and holm yield with increase in distance from $C$. mopane trees indicated a competitive effect of the tree on crop yield. The competition was for resource utilization like soil water and nutrients. Since there were very less difference in soil nutrient due to distance from tree, the competition was mainly for soil water utilization. A regular rain of required quantity probably caused withdrawal of soil water by trees as well as the agricultural crop from the same soil layer. Such type of water use by the integrated tree reduces soil water availability for the crop and reduce crop yield. Relatively greater reduction in grain yield as compared to husk suggested that the effect of competition for soil water was severe on grain filling and yields. Low SWC in 0-25 in August and 25-50 cm in September 2003 suggested that tree utilized soil water from the same layer from which $V$. radiata was utilizing. At less water availability in topsoil layer, tree used to utilize soil water from the deeper soil layer as evidenced by reduced soil water in 50-75 cm soil layer in December 2003.

\section{Concluding remarks}

Despite of favourable influence by reducing solar radiation and enhancing crop water status in tree-integrated plots, there was significantly high reduction in yield of $V$. radiata. Tree size, competition for resources and soil water deficit were the factors affecting crop yield. Availability of optimum amount of soil water for agriculture crop 
resulted in high completion between tree and agriculture crop for water use thereby reducing population and growth of associated crop. When a decline in soil water in top soil layer occur, tree use to withdraw soil water from deeper layers and improves soil water in upper soil layers thereby indicating facilitative effect under adverse condition. A transition from strong competitive to weak facilitative between August and December suggests the dominance of competitive effects over facilitation across a gradient from favourable to soil water stress conditions (Bertness and Callaway, 1994). Thus, a farmer cannot enhance crop production by integrating $C$. mopane tree when rainfall is sufficient only for agriculture crop. Silviculture practices like trenching around tree trunk to reduce overlapping of roots of trees and crop and therefore competition for resources may be beneficial for crop production when $C$. mopane is integrated in agriculture land.

Acknowledgements. Authors are thankful to the Director, Arid Forest Research Institute for providing necessary facilities to carry out this experiment.

\section{REFERENCES}

[1] Aggarwal, R.K., Kumar, P. (1990): Nitrogen response to pearl millet grown on soil underneath $P$. cineraria and adjacent open site in an arid environment. - Annals of Arid Zone 29: 289-293.

[2] Belsky, A.J., Mwonga, S.M., Amundson, R.G., Duxbury J.M., Ali, A.R. (1993): Comparative effects of isolated trees on their undercanopy environments in high- and low-rainfall savannas. - Journal Applied Ecology 30: 143-155.

[3] Belsky, A.J. (1994): Influence of trees on savanna productivity: tests of shade, nutrients, and tree-grass competition. - Ecology 75: 922-932.

[4] Bennet, J.G. (1983): A field guide to soil and site description in Zimbabwe. - Technical Hand Book No. 6. Government Printer, Zimbabwe, 60p.

[5] Bertness, M.D., Callaway, R.M. (1994): Positive interactions in communities. - Trend in Ecology and Evolution 9: 191-193.

[6] Bone, L., Lawrence, M., Magombo, Z. (1997): The effect of a Eucalyptus camaldulensis (Dehn) plantation on native woodland recovery on Ulumba Mountains, Southern Malawi. - Forest Ecology and Management 99: 83-89.

[7] Brenan, H., Kessler, J.J. (1995): Woody plants in agroforestry systems of semi-arid regions with an emphasis on the Sahelian countries. - Springer-Verlag; Berlin, Germany.

[8] Browald, M. (1997): Changes in soil mineral nitrogen and respiration following tree harvesting from an agricultural system in Sweden. - Agroforestry Systems 35: 131-138.

[9] Callaway, R.M., Brooker, R.W., Choler, P., Kikvidze, Z., Lortie, C.J., Michalet, R., Paolini, L., Pugnair, F.I., Newingham, B., Aschehoug, E.T., Armas, C., Kikodze, D., Cook, B.J. (2002): Positive interactions among alpine plants increase with stress. Nature 417: 844-848.

[10] Coates, P. K. (1983): Trees of Southern Africa. - Struik, Cape Town, RSA, 959p

[11] Franco, A.C., Nobel, P.S. (1989): Effect of nurse plants on the microhabitat and growth of cacti. - Journal of Ecology 77: 870-86.

[12] Friedman, J., Orsan, G., Ziger-Cfir, Y. (1977): Suppressions of annuals by Artemisia herbaalba in the Negev Desert of Israel. - Journal of Ecology 65: 413-426.

[13] Fuentes, E.R., Otazia, R.D., Allindi, M.C., Hoffman, A., Poiani, A. (1984): Shrub clumps of the Chilean matoral vegetation: structure and possible maintenance mechanism. Oecologia 62: 405-411. 
[14] Gibson, A., Bachelard, E.P. (1986): Germination of Eucalyptus sieberi, L. Johnson seeds. I. Response to substrate and atmospheric moisture. - Physiology 1: 57-65.

[15] Greenlee, J., Callaway, R.M. (1996): Effects of abiotic stress on the relative importance of interference and facilitation. - American Naturalist 148: 386-396.

[16] Gupta, J.P., Saxena, S.K. (1978): Studies on the monitoring of dynamics of moisture in the soil and the performance of ground flora under desertic communities of tree. - Indian Journal of Ecology 5: 30-36.

[17] Hocking, D. (1993): Trees for Drylands. - Oxford \& IBH Publishing Co. New Delhi.

[18] Inchausti, P. (1995): Competition between perennial grasses in neotropical savanna: the effect of fire and of hydric nutritional stress. - Journal of Ecology 83: 231-243.

[19] Inouye, R.S., Byers, G.S., Brown, J.H. (1980): Effects of predation and competition on survivorship, fecundity and community structure of desert annuals. - Ecology 61: 13441351.

[20] Jackson, M.L. (1973): Soil Chemical Analysis. - Prentice Hall of India Private Ltd., New Delhi, India.

[21] Kater, L.J.M., Kante, S., Budelman, A. (1992): Karite (Vitellaria paradoxa) and nere (Parkia globosa) associated with crops in South Mali. - Agroforestry Systems 18: 89-105.

[22] Markham, J.H., Chanway, C.P. (1996): Measuring plant neighbour effects. - Functional Ecology 10: 548-549.

[23] Shankarnarayn, K.A., Harsh, L.N., Kathju, S. (1987): Agroforestry in arid zones of India. - Agroforesry Systems 5: 69-88.

[24] Singh, G., Gupta, G.N., Kuppusamy, V. (2000): Seasonal variations in organic carbon and nutrient avaialability in arid zone agroforestry systems. - Topical Ecology 41: 17-23.

[25] Singh, G., Gupta, G.N., Rathod, T.R. (2001): Growth of woody perennials in relation to habitat condition in northwestern Rajasthan. - Tropical Ecology 42: 223-230.

[26] Singh, G., Rathod, T.R. (2002): Plant growth, biomass production and soil water dynamics in a shifting dune of Indian desert. - Forest Ecology and Management 171(3): 309-320.

[27] Singh, G., Bala, N., Mutha, S., Rathod, T.R., Limba, N.K. (2004): Biomass production of Tecomella undulata agroforestry in arid India. - Biological Agriculture \& Horticulture 22(2): 205-216.

[28] Sokal, R.R., Rohlf, F.J. (1981): Biometry. $-2^{\text {nd }}$ edn. NewYork, USA: W.H. Freeman.

[29] Tielborger, K., Kadmon, R. (1995): Effect of shrubs on emergence, survival and fecundity of four coexisting annuals species in a sandy desert ecosystem. - Eco-science 2: 141-147.

[30] Tielborger, K., Kadmon, R. (1997): Relationship between shrubs and annual communities in a sandy desert ecosystem: a three year study. - Plant Ecology 130: 191-200.

[31] Vetaas, O.R. (1992): Microsite effects of trees and shrubs in dry savannas. - Journal of Vegetation Science 3: 337-344.

[32] Vitousek, P.M., Sanford, R.L.Jr. (1986): Nutrient cycling in most tropical forest. - Annual Review of Ecological Systems 17: 137-167.

[33] Walkley, A., Black, I.A. (1934): An examination of the Degtiareff methods for determining soil organic matter and proposed modification of the chromic acid titration method. - Soil Science: 37: 29-38.

[34] Wallace, A., Romney, E.M., Cha, J.W. (1980): Depth distribution of roots of some perennial plants in the Nevada site area of the northern Mojave Desert. - Great Basin Journalist Memoirs 4: 201-207.

[35] Wilson, S.D. (1993): Competition and resource availability in heath and grassland in the snowy mountains of Australia. - Journal of Ecology: 81: 445-451.

[36] Wilson, S.D., Tilman, D. (1991): Component of plant competition along an experimental gradient of nitrogen availability. - Ecology 72: 1050-1065. 